\title{
SCIENTIFIC ASPECTS OF SPATIAL ECONOMIC ALLOCATION OF ENTREPRENEURIAL ACTIVITIES
}

\author{
Tatjana ŠTAUBE ${ }^{1}$, Ineta GEIPELE ${ }^{2}$ \\ ${ }^{1,2}$ Riga Technical University, Institute of Civil Engineering and Real Estate Economics, \\ Kalnciema Street, 6 - 210, Riga, LV-1048, Latvia \\ Corresponding author e-mail: tatjana.staube@rtu.lv
}

\begin{abstract}
The paper includes results of economic calculation until 2020 regarding adaptations of the algorithm model of forecasting supply of spatial economic objects for planning the development of the Latvian high-end industrial market space. Scientific discussion concerns the average temperature increase as a determinant ratio and the definition of spatial economics developed by the authors The research focuses on the changes in climatic conditions, which may have an impact on the country's economic development priorities. The paper also reflects on assessment of regional specialization of the leading entrepreneurial activities in Latvia and the Baltic States. It is mainly based on the empirical study of scientific literature. The authors apply the following methods: decision-making, analysis of primary and secondary sources, the Gini coefficient of Regional Specialization, the Gini coefficient of Geographical Concentration, logical approach and comparisons, systems and dynamic factor analysis, expert analysis, mathematical statistical methods. Main conclusions state that Latvia would continue regional development, maintain division of industrial capacities and decrease of Riga's industrial agglomeration. Agriculture will develop intensively. Increase in high-class industrial property stock is partly conditioned by the high-quality manufacturing needs, as well as logistics and service needs. The calculated level of that stock is 772,300 sq.m until 2020. In fact, Latvia demonstrates low regional specialization rates for agriculture and manufacturing. The authors stress importance of development of the appropriate infrastructure in creating competitive local business environment in the Latvian cities.
\end{abstract}

Keywords: Baltic Sea Region, climate change, industrial location, location attractiveness, multinational enterprise, regional specialization, spatial economy.

\section{INTRODUCTION}

Global initiative for smart city development in Europe involves establishing a partnership to bring investments into development of human and social capital, infrastructure, to implement wise management of natural resources in order to ensure sustainable economic development. In this regard, the authors note that there is rather poor presentation of the Latvian cities in comparison with the cities from the developed countries, for instance, comparing information on Riga and London (European Commission, Smart Cities Stakeholder Platform, 2014). It is worth 
mentioning that in the 2007 research report (Vienna UT, 2007) on the middle-size European cities, where the Baltic States presented only one city per country, the capital of Latvia Riga was not recognized a smart city, whereas the city of Liepaja was. Riga's municipality has been working on creating a smart city environment (Zajacs et al., 2014; The New Economy, 2014). Energy efficiency and modeling or system solutions are among the issues contributing to establishment of the smart cities platform. Therefore, scientists, government authorities and business professionals should develop a partnership to provide information and recourses to smart cities platform development. The authors believe that it would promote sharing knowledge and increase motivation of the local society to develop sustainable economic environment in a neighborhood and/or region.

With the reference to the European Commission's workshop report (2011), a concept of the smart cities considers a mobility, competences and partnership of business and public sector with a direct focus on energy efficiency and satisfaction of the needs of the citizens. In the framework of the given research, the authors deal with the issue of spatial economics and offer new scientific solutions for real estate development in Latvia. The development of the commercial real estate object as a spatial economic object is the object of research, whereas spatial economic allocation of entrepreneurial activities in Latvia is its subject. The research aims to analyze opportunities to improve conditions to develop sustainable business environment, find the balance between manufacturing and agricultural capacities, and explore consumer market expansion alternatives.

The following objectives are defined to the research:

1) to evaluate significance of the climate change instrument in the context of spatial economic allocation and develop the algorithm model of forecasting supply of spatial economic objects taking into account the potential climate change and economic growth, to provide solutions for development of the market of spatial economic objects in Latvia;

2) to summarize the determinants of spatial economic allocation of entrepreneurial activities and the results of assessment methods of regional concentration of entrepreneurial activities and their specialization within the framework of the performed empirical analysis of the location of spatial economic objects, and determine the degree of this specialization in Latvia and the Baltic States.

The concept of spatial economy has been used in the literature relatively recently - during the period of last twenty-five years of scientific research and development of the European Union it has been used in official documents. The first widely recognized collection of information on spatial planning and territorial cooperation was published in 2010 (Dühr et al., 2010). Scientific and practical relevance of the research is closely connected to current active discussions of the issues related to agglomeration, industrial location, shortage of territories in the European market, along with the development of an eco-effective economy. For instance, in scientific conferences of global and local scale, organized by AESOP (Association of European Schools of Planning), WSEAS (The World Scientific and Engineering Academy and Society), BMDA (Baltic Management Development Association), EURO (Association of European Operational Research Societies), as 
well as in ICSSS (International Conference on Social Sciences and Society), the World Congress of the Latvian scientists, the World Sustainability Forum and professional conferences such as, Earth Summit, ERES (The European Real Estate Society), and within the framework of a number of international programmes, such as, ESPON (European Observation Network for Territorial Development and Cohesion) and INTERREG (European Interregional Cooperation Programme).

Research methodology. The solutions and models as results acquired in the course of research have been developed on the basis of decision-making, analysis of current official documentation (use of primary and secondary sources), study of economic criteria, such as level of employment, urbanization, flow of finances applying the logical approach and comparisons, systems and dynamic factor analysis methods, expert analysis and mathematical statistical methods. The authors used complex calculation result data from the globally significant project ENSEMBLES, statistics from the European Commission, databases of the state central statistical offices of Latvia and other countries, scientific papers published during the development of the scientific research related to climate change and economic recovery issues.

The following empirical works were analyzed according to the research field:

- spatial economics, territorial development and cooperation (Albers H., Ando A., Arauzo-Carod J., Dühr S., Faludi A., Finka M., Fujita M., Hayter R., Kasper W., Krugman P., Manjon M., Shogren J., Venables A., Waterhout B. etc.),

- commercial real estate development, location analysis, land use (Auzin̄š A., Farinos D., Gromley R., Hanink D., Healey P., Lambert J., Vanags J., Yap J. etc.),

- $\quad$ sustainable development and climate change (Āboliņa K., Brizga J., Kḷaviņš M., Piccin J., Staniškis J. etc.),

- strategic management, creation and cooperation of the multinational companies, analysis of the foreign capital flow, strategic planning and modeling ((Akgüngör S., Andersson L., Barrios S., Dicken P. , Dunning J., Falcioğlu P., Geipele I, Kaklauskas A., Kotler P., Kronborg D., Le Bas C., Mahama H., Mezias JM., Narula R., Paluzie E., Petersson L., Suedekum J., Sierra C., Thomsen S., Traistaru I., Zavadskas E., Yeaple S. etc.).

Study materials and scientific literature available in Latvia and abroad, internationally recognized professional literature developed and available in the local market and abroad and the following official papers: the European Union, "National Lisbon Programme of Latvia", the European Union "Sustainable Development Strategy", "Land Policy Guidelines from 2008 to 2014", "Spatial Planning Development Law", the Ministry of Economics "Action Plan to Improve Business Environment in Latvia", "Guidelines on National Industrial Policy of Latvia from 2013 to 2020", Ministry of Environmental Protection and Regional Development "Sustainable Development Strategy of Latvia until 2030", Riga City Council "Long-term Development Strategy of Riga until 2025" and other official documentation was used as the theoretical foundation of the given scientific work. 
The authors used specialist knowledge gained from professional work experience in the field of real estate development, market research and financial analysis.

The following limitations and implications were defined within the research:

1) Two types of commercial real estate market objects allocation principles were analyzed. Primary attention was focused on the industrial property objects where the premises were classified as suitable for production.

2) There is a certain time lag in statistical data update due to the frame of the current scientific Research and terms of information processing of the responsible organizations. Hence, a part of the research containing information of historic importance is developed by the authors on the basis of dynamic factor analysis to show the actual development tendencies. The year of 2009 was accepted for forecasting of modern industrial real estate properties stock as a period appropriate for all counties to build conservative forecasting that 1) reflects the market conditions after the world economic crisis, 2) complies with the requirements for developing conservative scenario, 3 ) reflects the circumstances of fast development of real estate market in the previous years and 4) accounts for the principle of gradual recovery of the economy. In the assessment of regional concentration and specialization of entrepreneurial activities the authors tended to reflect a full decade data to ensure adequate comparison for three Baltic countries, therefore, in subchapter 3 the research has a time span limitation from 2000 to 2011.

3) The process of data analysis has shown that climate change monitoring and research institutes operating in the European Union have no unified specialization or purpose for utilization of the results. To objectively evaluate climate change indicators of several counties, in the analytical part it was decided to rely on the ENSEMBLES project data. According to the official information, the data is a result of several sources on climate change monitoring. The climate change factors of 2035 are accepted for 2020 in accordance with other statistical data limitations.

Within the given scientific paper, the authors present the following scientific novelties:

1) The outcome of the innovative research based on the application of the ENSEMBLES project data is the developed algorithm model of forecasting supply of spatial economic objects. The authors have developed the model algorithm and its practical solutions.

2) For the first time regional specialization and concentration rate of the main entrepreneurial activities has been measured and assessed applying Gini coefficient method for Latvia and the Baltic States.

Practical application and approbation of research results are presented in the authors' scientific publications developed in the framework of international scientific conferences, seminars and research projects (Staube, 2013, 2014; Staube \& Geipele, 2010, 2011a, 2011b, 2012 a, 2012 b; 2013a, 2013b). 


\section{SCIENTIFIC FOUNDATION FOR THE CONCEPT OF SPATIAL ECONOMICS}

There are certain essential terms that define the basics to the content of spatial economics. Using new tools, in particular, modeling techniques developed to analyze industrial organizations, international trade, and economic growth, the "new economic geography" has emerged as one of the most exciting areas of contemporary economics (Fujita et al., 2001). New economic geography creates spatially stylized models of international trade and patterns of urban activity defined by the processes of agglomeration and dispersion (Albers et al., 2010).

In the glossary of the Council of Europe, spatial planning refers to the methods used by the public sector to influence the distribution of people and activities in spaces at various scales as well as the location of various infrastructures, recreation and nature areas (CEMAT, 2007). Spatial planning evaluates policy of regional development so that balanced relation of territorial conditions is created for favorable environment, economic development and permanence of society of territorial citizens (Shepherd and Bouckova, 2004). The planning process is about setting the frameworks and principles in order to guide the location of real estate development and infrastructure. It involves rules and regulations giving certain groups or individuals the right to use land and provides authorities with the means to exert their influence on land use. The planning process includes local and national policies, rules and regulations and planning traditions (Healey, 2005). Spatial planning is a significant element of land management where thematic graphical and cartographic material is broadly used. Spatial planning is linked to sustainable development (Auziñš, 2008).

The sustainable European development is planned within four interrelated dimensions, namely economic development and environmental sustainability, infrastructure and transport, and urbanization (social and physical) (CEMAT, 2007).

Sustainable development is a broad concept. Many different definitions of the concept include a temporal perspective, which entails a cross-generational responsibility, and a spatial perspective, which entails cross system application (Shcherbina et al., 2010). Weak sustainability is based on the acceptance that welfare and sustainability are not dependent on any special form of the capital, but are secured by the growth of land capital reserves. In this regard, hardly comparable aspects by value and transposability ratio would be acceptable (Brizga, 2012).

According to the scientific findings presented in the proceedings of International Conference on Social Sciences and Society (Staube \& Geipele, 2011b), the aim of territorial cooperation (European Commission, 2013; Waterhout, 2011) is to facilitate territorial integration and promote more competitive and sustainable forms of territorial development. Territorial potential is determined by a series of factors (geographical location, production, infrastructures, climate, natural resources, agglomeration economies provided by its business network) (CEMAT, 2007). Mission of development of a territory is to assess territorial potential necessary limitations at all administrative levels and economy branches, provide rational use of land resources and guarantee the rights to use and develop real estate according to spatial planning (Auziņš, 2008). Within the $2^{\text {nd }}$ World 
Sustainability Forum the ontological approach to sustainability and practical suggestions were discussed. Industrial sector expansion causes environmental impacts and local population as well as the territorial development is under the risk of bureaucratic decisions. The concept of eco-industrial parks seeks to minimize the environmental impacts in industrial areas by working together as a community (Piccin, 2012; Elabras Veiga and Magrini, 2009). With regard to Rio-10 Summit and the Lowell Center's definition of sustainable consumption and production, Staniškis reports to understand the currently fundamental mismatch between generating welfare for people and the stability of the carrier system Earth (Staniškis, 2012).

Strategic planning looks beyond the existing conditions trying to project the market situation in future five or ten years. Marketing specialists must be prepared for changes in the market as well as political, cultural, technological and economic changes (Geipele, 2007).

New economic geography models assume that geographical advantage is endogenous and suggest that regional specialization might be the result of the spatial pattern of agglomeration of economic activities (Krugman, 1991; Traistaru et al., 2002). Because of firm relocation and due to monopolistic competition, the variety of goods available in the receiving region increases. As labour demand rises in the receiving region, wages increase, which in turn attracts workers to follow the manufacturing firm. Thus, this initial relocation will produce cumulative effects, causing both firms and workers to relocate from the 'donor' region to the 'receiving region'. With no barriers to the movement of firms or manufacturing workers (like in the Krugman model) (Krugman, 1991), a bleak scenario could be imagined: the manufacturing sector in the 'donor' region would collapse and manufacturing would concentrate in the 'receiving' region. This scenario could develop gradually following the lowering of trade costs. Initially, when trade costs are high, a situation where manufacturing is evenly split between regions (each region produces for its own local market). That hardly could be possible in the Baltics due to the smallscale markets of each country region, cultural differences and low pan-Baltic migration dynamics and "low inter-EU country mobility" (Eichengreen, 1993; Obstfeld and Peri, 1998; Traistaru et al., 2002).

Krugman's analysis focuses on a model similar to the two sector-two region model of Krugman and Venables (1990), but in this case, each sector (agriculture and manufacturing) uses a specific factor of production and only the factor specific to manufacturing (industrial workers) is mobile between regions. Two regions are identical in their initial factor endowments. Relocating firms and workers from one region to the other triggers agglomeration. The developed neo-classical trade theory (Ohlin, 1933; Ricardo, 2004; Traistaru et al., 2002) explaining the phenomenon of intra-industry trade in Krugman models assumes that geographical advantage is endogenous and suggests that regional specialization may be the result of the spatial pattern of agglomeration of economic activities (Krugman, 1991).

Comprehensive (integrated) planning as opposed to sectoral planning that is a process involving drawing together of level and sector specific planning efforts, permits strategic decision-making and provides a synoptic view of resources and commitments. Integrated planning acts as a focal point for institutional initiatives and resource allocation. In the context of integrated (or comprehensive) planning, 
economic, social, ecological and cultural factors are jointly used and combined to guide land- and facility-use decisions towards sustainable territorial development (CEMAT, 2007).

Considering the "competition effect" (Barrios et al., 2005), "local market particularities" (Auziņš, 2004; Grizāns and Vanags, 2010; Kaklauskas et al., 2011; Teirumnieks, 2010) and "investment environment" (Vanags and Geipele, 2008; Brazinskas, 2008; 126; 186; Tvaronavičius and Tvaronavičiene, 2008), "locational strategy" (Hanink and Gromley, 1987; Le Bas and Sierra, 2002), "multinational cooperation" (Yeaple, 2003) and "agglomeration economies" (Alanon et al., 2007; Arauzo and Viladecans, 2009; Crozet et al., 2004; Fujita, 2001) for the countries with the unbalanced commercial real estate market development, like it is stated for Latvia, the authors distinguish two general blocks: regional economic planning and real estate business as a support function to industrial market development. The emphasis on the regional economic planning is often directed towards stimulating commercial environment of regions in a country.

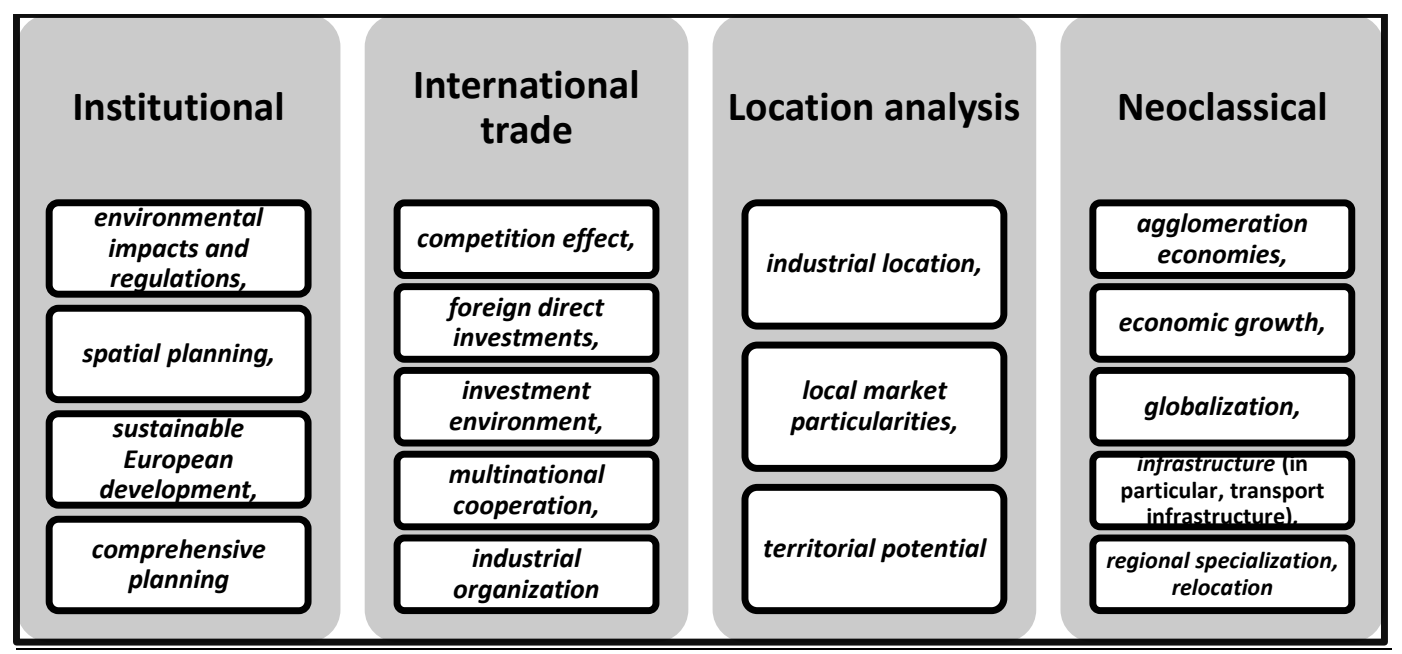

Fig. 1. Identification of the content of spatial economics: Indicators (factors, terms) per group of determinants [presentation of analysis made by authors].

Based on the research results, the authors enunciate the following definition: spatial economics is a field of modern economic science, where the models are developed and a set of criteria (determinants and conditions) systems of production capacity and related business activities, rational distribution and movement in place and time, following the principles of sustainable development and developing real estate market development trends is analyzed. The authors focus attention on the interaction of three groups of business areas highlighted in the study: 1) manufacturing and agriculture, 2) commerce and services, and 3) construction as a support industry, which in total significantly influences the development of real estate in Latvia. As a result of the research, the authors conclude that the aforementioned areas are the ones, which shape the functionality of the territory of Latvia. Thus, manufacturing, which creates employment and facilitates economic development, currently is still in a destructive stage due to the lack of support from the government, which is both a consequence of the recent regaining of Latvian 
independence and the global economic recession. Agriculture, which is the traditional industry and which due to increased competitive conditions upon Latvia joining the European Union, has lost its share in the economy, still forms the cultural and social environment. Latvia's advantageous geopolitical position of a country located on the border of Europe and Russia is naturally a favorable basis for the development of trade and services. Due to its economically advantageous geographical location linking large and powerful investors - the countries like Russia and the block of Scandinavian states, Latvia could cumulate all its force on servicing these big neighbors, but it does not (Staube \& Geipele, 2012b). For this purpose, Latvia must have very strong professional specialists and well developed infrastructure. The rating of local specialists had been remarkably rising for the past decade due to Latvia's integration into Europe and Latvian inhabitants' natural cultural characteristics of ambitious leadership. Regarding the small scales of Latvia, the retail trade has also become a traditional industry in Latvia along with the services sector, due to the influence of globalization, which is developing rapidly.

The authors' reading of a spatial economic location of the business (entrepreneurial) activities is presented in the scheme in Figure 2. It comprises three interactions units: two business units, where the collaboration partner is another businessman, developer, realtor, supplier, construction contractor, either a public authority or any other business unit except local inhabitants, which are defined as a society in the context; and the local society, which is involved as a labour force.

In the context of development of the industrial property market, the presented scheme suggests that the spatial economic location is a territory of placement of the business or entrepreneurial activities analyzed as a system. This location may be presented as a place of producing, promoting or selling and buying the goods. The location is developed as the commercial real estate property with a growing value added. It is not a building but a spatial item that has a surface and surroundings. In that location a commercial real estate object as a spatial economic object is developed. Local authorities might provide the advanced transport infrastructure and communications in support of the current location development for the interest of the country's territorial development.

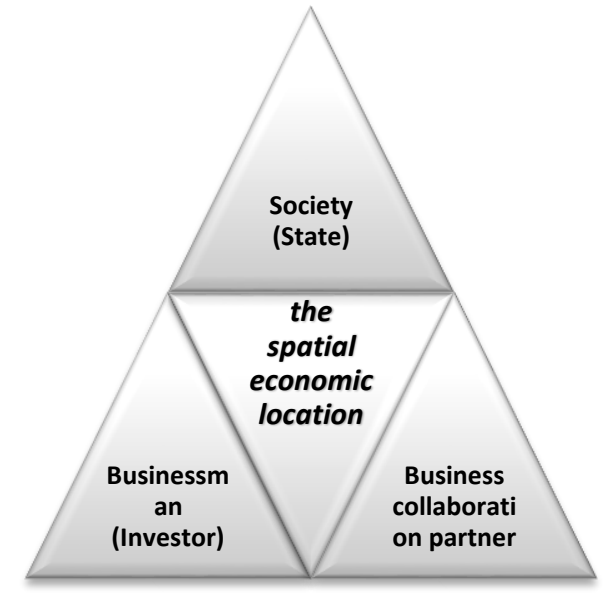

Fig. 2. Scheme of spatial economic location's identification in the system of entrepreneurial activities [developed by authors]. 
The analysis of the economic activities in the neighboring countries is indispensable input into the economic recovery process. The authors analyzed the Baltic Sea Region in the frame of territorial development and spatial planning adaptation and evolution for Latvia. The Baltic Sea Region (hereinafter - BSR) includes the following areas: EU member states Denmark, Estonia, Finland, Latvia, Lithuania, Poland, Sweden and northern parts of Germany, as well as the neighboring countries of Norway, north-west regions of Russia and Belarus. Two radiuses of entrepreneurial activities destinations or territory's cooperation and impact radiuses are developed. The first radius indicated for Latvia includes the border states: Lithuania, Estonia, Russia and Belarus. The second radius accumulates investments assets of the countries in the closest proximity to the Baltic Sea Region: Finland, Sweden, and Norway and next to the neighboring overland partners Ukraine and Poland.

Figure A1 (see Appendix 1 to the present paper) was presented at the International Conference on Environmental Engineering (ICEE) in Vilnius in May, 2014 (Staube, 2014).

Referring Staube (2013), "Modeling of climate change projections" or A section of the research includes the following steps:

A1. The atmospheric temperature data projected for 2035 accepted for Latvia were compared to the rest of the Europe's historical average data fixed in 19611990 from the ENSEMBLES project (see sample in Fig. 3).

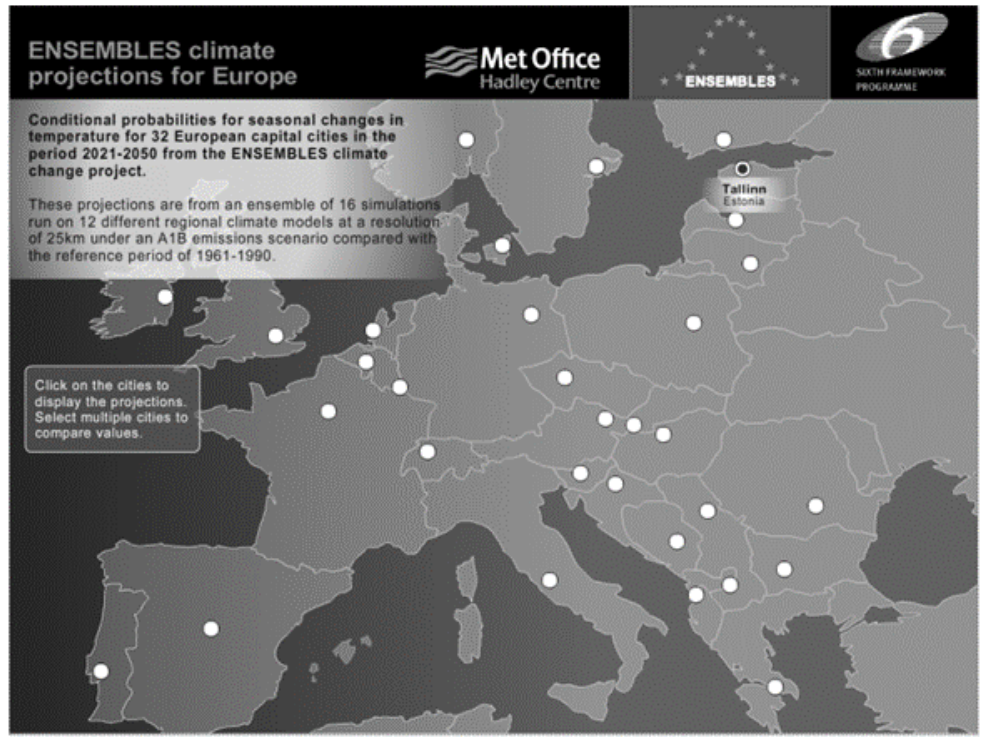

Fig. 3. Image of the ENSEMBLES climate projections map for Europe, a copy from Met Office centre's database [copy from: the Met Office, 2010a].

A2. Deviation limitation assumption of $+/-0.5^{\circ} \mathrm{C}$ was made for comparing the retrieved statistics on the seasonal atmospheric temperature projections.

Initiated discussion on the influence of the factors is the authors' invitation to the specialists of the environment research scope to measure the relevance and necessity to add more factors of the climate change that possibly may change the 
results. Precipitation, wind speed and other indicators are listed in Table 1 in the next subchapter.

Herewith, "Making a forecast on the high-class (modern) industrial property stock and manufacturing capacity" or B section of the Research concerns the following points:

B1. Structural analysis of the national economies development for the countries under comparison was conducted based on the following assumptions: 2009 is accepted as a determinant year with effect from financial crisis to build conservative projections. In the course of analysis, the Latvian economy development data was compared to 1998, when the economy was not stable in general after regaining of independence, but the policy was focused on the development and joining the European Community (from 1996 till the middle of 1998 the average annual GDP growth was 6\% (Ministry of Economics of the Republic of Latvia, 2013). Results of 1998 were partially affected by the beginning of the Russian economic crisis that made the natural adjustment to the economy of Latvia (Staube \& Geipele, 2010; Ministry of Economics of the Republic of Latvia, 2013). Two periods for Sweden were observed, namely, before and after it joined the European Economic Community in 1995: the years of 1984, 1998, 2009, the Czech Republic's statistics was calculated since recognition of its independence, the years of 1995, 1998 and 2009. For making interim projections, statistical indicators of 1998 were studied for all countries. The data sources are national and EUROSTAT statistics.

B2. The data were collected and recalculated according to gross domestic product (GDP) deflator's formula.

B3. 2005 is the chain-linked reference year of the statistics.

The authors have come to a conclusion that the character of the dynamic series of the added value produced in the national economy during longer time period in comparable prices significantly differs from the character of the added value of the series in actual prices.

B4. Comparison and forecasting of the potential growth in value added of manufacturing in GDP were made from the compound average annual growth rate formula (Orlovska, 2007).

B5. Forecasts of 2020 are a milestone in making projections for 2035. The GDP volume in 2020 in Latvia was adopted from the World Economic Prospects 2010 (Euromonitor International, 2010) and Austrian Academy's of Sciences on the population prognosis (Scherbov et al., 2008; Staube \& Geipele, 2010).

B6. Comparison of manufacturing gross value added per 1 sq.m of modern industrial property in Sweden is done on Stockholm's data recalculations (The Times, 2013), information on Sweden overall is not available, $56 \%$ is taken as large cities' value in the total manufacturing in Latvia (Central Statistical Bureau of Latvia, 2011).

B7. The comparison of value added of manufacturing is made with the planned for 2020 in the Latvian National Development Plan (Cross-Sectoral Coordination centre, 2012). 


\section{SCIENTIFIC ECONOMIC FOUNDATION AND SIGNIFICANCE OF CLIMATE CHANGE INSTRUMENT IN SPATIAL ECONOMIC ALLOCATION}

Environmental changes come to the front of spatial planning making the societies to exchange technologies and knowledge on the regions' geo, flora and fauna particularities. Environmental impact assessment is related to the climate change issue. The warming had been caused by human activity; changing land use was named among the major reasons (Camagni, 2005; the Met Office 2010b). Land uptake by urban development and transport infrastructure has been slightly faster than in the previous decade. This continues the trend of landscape fragmentation and increases other environmental impacts. Urbanization rates vary substantially, with coastal and mountain areas among the most affected regions in Europe. Current land use trends are likely to continue though possibly at a lower rate, with built-up area increasing at the expense of agricultural land uses and natural areas (EEA, 2010). In 2000, the International Association for Impact Assessment conference in Hong Kong served as an initial forum establishing the framework for integration of strategic environmental assessment.

Weather (outdoor weather, weather conditions) is the condition of the atmosphere at any given time. Weather conditions are determined by the following factors: air temperature, air pressure, humidity of the air, amount and kind of precipitation and if any of these conditions changes, the weather changes as well. Climate is the composition of weather conditions of a particular region over a long period that is formed as the result of the solar radiation, the peculiarities of the Earth's surface and the associated atmospheric circulation processes. Climate of the certain area is much more permanent than the weather conditions of this area. Causes of climate change can be both natural ongoing processes and human activities, primarily affecting the composition of the atmosphere, as well as the ways of land use (Ābolina et al., 2008).

According to statistics, global average temperature rise exceeding 2 degrees ${ }^{\circ} \mathrm{C}$ during the century can lead to the extinction of about $40 \%$ of existing species, which may bring significant losses to agriculture.

In parallel with the devastating natural processes, among which the average atmosphere temperature increase is the most important process as this can lead to an increased risk of fire in forests, changes in soil fauna affecting soil structure and fertility, distribution of plant diseases and pest species, ecosystem adaptability have been observed as well (Kḷaviņš and Āboliņa, 2008). Undoubtedly, these determined risks should be considered as important aspects of the preservation of the ecosystems. In Latvia as well as elsewhere in Europe for several years, scientists have observed local flora and fauna changes: birds are arriving earlier in spring and their nesting and feeding habits related to food availability for a longer period are also changing. Occurrence of new bird species, a significant prolongation of the growth period, trends of extension of the vegetation season for some trees and hence, productivity of forests and opportunities of growth productivity for many agricultural crops have been recognized (Ābolina et al., 2008; Ministry of Agriculture of Latvia, 2010; the State Forest Service, 2010). 
In the world, there are different methods used in the models of climate change prediction (Ābolinga et al., 2008; the Met Office 2010b; Pope, 2007) including increase of $\mathrm{CO} 2$ emissions or reduction of the impact of the economic and social growth. All models highlight that the Earth's global warming continuously extends to all regions, mainly due to the existing atmospheric pollution.

Land use is a component of spatial planning. Earth's resources, land rent, and the geopolitical position of the country determine the ways of land use and direction of national economic development. Depending on the changes of climatic conditions, the country's economic development priorities can change.

Thus, working on the model, which aims to identify volume of spatial economic objects within the long term and sustainable development perspective, the issue of climate change cannot be ignored. The main significant meteorological and climatologic factors suggested by the Met Office scientists for industrial real estate location development planning are listed in Table 1.

Table 1. The relevant meteorological and climatologic factors for industrial real estate location development planning [developed by authors]

\begin{tabular}{|c|c|}
\hline Important indicators & Other significant factors \\
\hline $\begin{array}{c}\text { Temperature: max, min: daily, monthly, } \\
\text { annual, 30+ year }\end{array}$ & Soil moisture \\
\hline $\begin{array}{c}\text { Precipitation: max: daily, monthly, annual, 30+ } \\
\text { year, }\end{array}$ & Pluvial flooding \\
\hline Snow and ice accumulation & River flooding \\
\hline $\begin{array}{c}\text { Wind speed: max: daily, monthly, annual, 30+ } \\
\text { year }\end{array}$ & Storm surges \\
\hline Gust level & - \\
\hline Ground level and at height & - \\
\hline
\end{tabular}

Source: unpublished material, 2013

There are other meteorological considerations, such as air quality (from noise or pollution), which also influence the location and design of the buildings. The importance of the scope of meteorological and climatologic factors may differ with the building type. The supporting infrastructure would have to be included (power, drainage, water supply) into the detailed study at the real estate project's development stage.

The following climate change factors have been observed to influence the Latvian territory:

1) increase of the number of dryness periods in summer (accepted to be determinant in the research);

2) high temperatures in winter (accepted to be determinant in the research);

3 ) increase of heavy rains, vehement winds and wind waves incidents;

4) increase of a flooding risk - the territories prone to flooding risk and periodicity of flooding incidents increase in Latvia and the scope of damage during river floods or wind waves at the sea coasts, including the washing away the coastal territories at storming weather, grows (Ābolina et al., 2008). 
When developing a specific model of sustainable development, which aims to identify the potential size of industrial space real estate market, the issue of climate changes cannot be ignored.

Process modeling is the basis for process management. In the study estimates, data projections are affected by the historical data fixed in the 20th century. Introducing the algorithm model of forecasting supply of spatial economic objects, the authors relied on the ENSEMBLES project, a scientific prediction system for climate change as one of the options with multidimensional calculation results in global and regional Earth System models. In accordance with the results of the analysis of the mean temperature in Europe, it is forecasted that over the next 25 years the annual temperature increase will be $1.52{ }^{\circ} \mathrm{C}$ in summer and $1.64{ }^{\circ} \mathrm{C}$ winter. Analyzing Riga average summer $\left(+17.2^{\circ} \mathrm{C}\right)$ and winter temperature forecasts $\left(-1.8^{\circ} \mathrm{C}\right)$ for 2035 , a standard deviation range of $+/-0.5^{\circ} \mathrm{C}$ was determined.

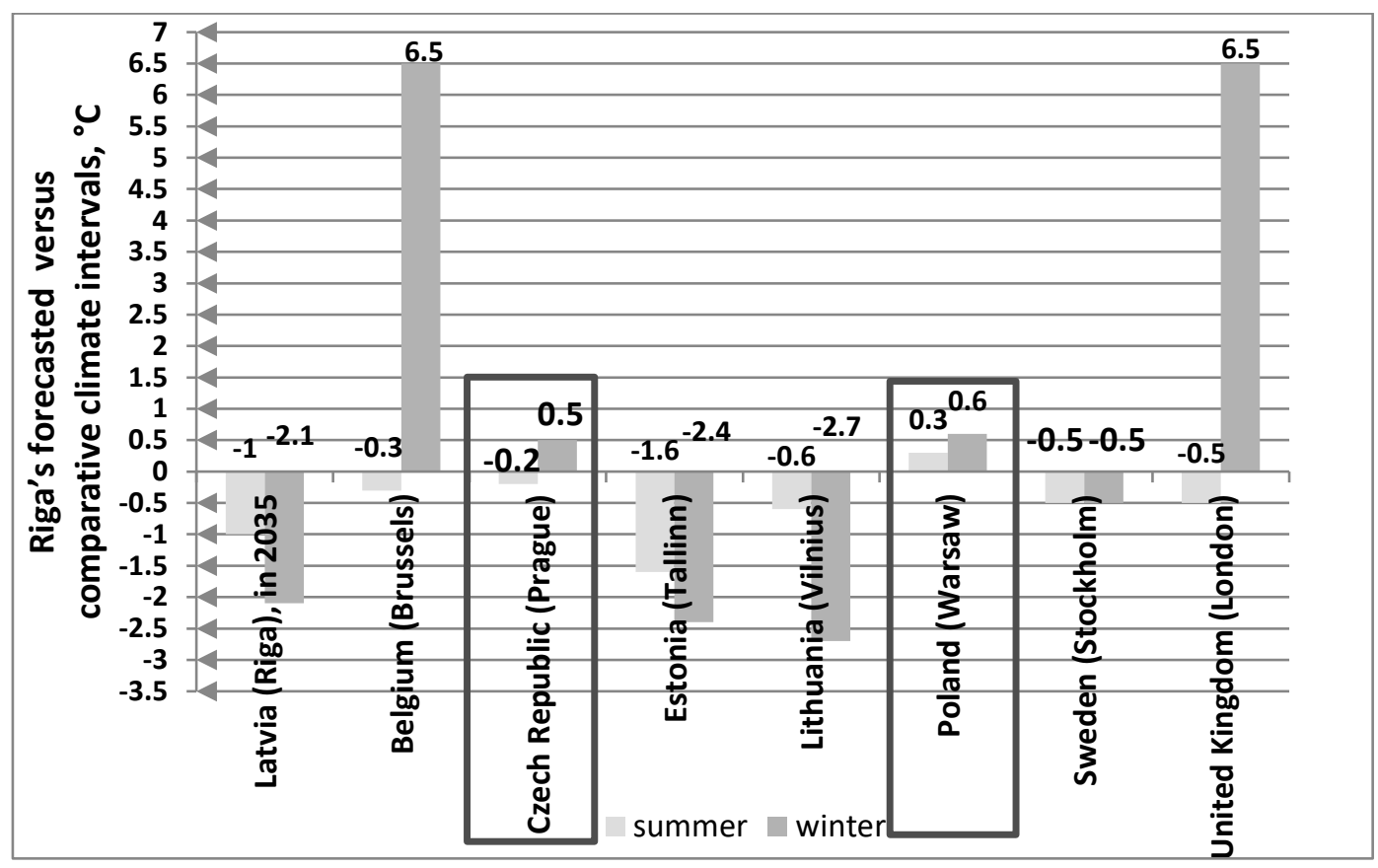

Fig. 4. Comparison of Riga's summer and winter atmospheric temperature Y2035 data with historical average data, retrieved from the ENSEMBLES project [calculations and presentation made by authors].

The data show that summer and winter temperatures of the climate change in Riga in 2035 is comparable to the Prague and Stockholm fixed atmosphere temperature indicators. According to the data indicated in Fig. 4, it can be concluded that summer temperature indicators are mostly within the limits of acknowledged deviation. In Fig. 4, the results of Latvia comparison with Czech Republic and Sweden are resumed in the experimental investigation ("Indicators", "Step1" of the algorithm model of forecasting supply of spatial economic objects and A1-A3 in the previous sub-chapter). 
Complete climate match in nature cannot be found and reached. Countries are located in different geographic areas of the natural environment: Latvia - on the Baltic Sea coast, it has a relatively mild and humid climate, the Czech Republic is in the a middle of the continent, in the mountain area of Central Europe, far from the coastal area, which is characterized by a moderate continental, but mild climate, but Sweden is under the influence of the Atlantic air masses. Sweden has a transition climate - from the maritime to the continental as its east coast is completely laved by the waters of the Baltic Sea, but to the West there is the territory protected by a mountain area (Latvian Tourism Development Agency, 2010; Worldtravels, 2010). However, south of Sweden is characterized as a mild climate area. Since in Latvia, Czech Republic and Sweden there are common climate features - mild character of climate and comparable forecasted temperature indicators within acknowledged deviation, the authors perform analysis of economic statistical data of the afore-mentioned countries.

According to the presented statistics, the highest value added is generated by the industry sector (30\%) in the Czech Republic. Following the global ratings, the Czech Republic, despite its small independence experience, has been ranked in the list of advanced economies. While in Latvia the most common sectors are retail and wholesale trade, public services, catering business and communication services, which means that a higher proportion is made by service provision sectors. In Sweden, the proportion of agriculture in GDP is similar to the indicator of the Czech Republic (2\%), but the industry sector is lagging behind the share of the rest of the service sectors by 5 percentage points. In Latvia, agriculture has a higher proportion of value added in comparison with the Czech Republic and Sweden. At the end of the twentieth century, in the GDP structure of Latvia the industry sector had significantly greater proportion and, thanks to the rapid development of trade, it was close to the Swedish index of 2009. By contrast, during the ten-year period, the turnover share of the industry in GDP structure fell faster than in the rest of the economy, while the largest increase was observed in business and financial intermediation activities sectors.

Latvian GDP forecasts for 2020 in accordance with the global market research company's Euromonitor International report data per 1 person amount to 17.029 U.S. dollars (Euromonitor International, 2010), or 13.402 euros. While according to the forecasting data of the Austrian Academy of Sciences, in 2020 the expected number of population is 1.803 million people (Scherbov et al., 2008). Thus, in 2020 the GDP of Latvia could reach 24.17 billion euro, which is 1.3 times higher than the amount of GDP in 2009. According to the analytics summarized from the official statistics (Central Statistical Bureau of Czech Republic, 2010; Central Statistical Bureau of Latvia, 2010; Colliers International, 2010; International Monetary Fund, 2010; King Sturge, 2010; National Central Statistical Bureau of Sweden, 2013; Shepherd and Bouckova, 2004) in Table 2, share of the modern industrial real estate market stock in Czech Republic in 2009 makes $31 \%$ of the modern industrial real estate market stock in Stockholm, but it more than 7 times exceeds the total supply of this market niche of Latvia. If the added values of the industry sector are compared in comparable prices, the indicator of Stockholm as 
the capital city is only 5 times less than the added value of the entire industry sector of the Czech Republic.

For the industry sector, during the period from 1998 to 2009, the Czech Republic and Sweden demonstrate almost similar average growth rates: 1.03 and 1.00, respectively. As to the final forecasting results for 2020 for Latvia, according to the Swedish data scenario, the share of the industry sector was proportionally aligned to the impact of the capital city and its surroundings (Riga with its suburban area) on the proportion of the total GDP of Latvia.

Table 2. The results of complex calculations of the Latvian industry's productivity and development of modern industrial premises scenarios, year 2009 in 2005 prices [calculations and presentation made by authors]

\begin{tabular}{|l|c|c|c|}
\hline \multicolumn{1}{|c|}{ Indicators/countries } & Czech Republic & $\begin{array}{c}\text { Sweden } \\
\text { (Stockholm) }\end{array}$ & Latvia \\
\hline $\begin{array}{l}\text { Manufacturing sector GDP, } \\
\text { billion euro }\end{array}$ & 41.33 & 8.9 & 2.1 \\
\hline $\begin{array}{l}\text { Modern industrial space market, } \\
\text { million sq.m }\end{array}$ & 3.36 & 11 & 0.45 \\
\hline $\begin{array}{l}\text { Industry GDP per 1 sq.m of } \\
\text { modern industrial premise space, } \\
\text { EUR / sq.m }\end{array}$ & 12,301 & 810 & 4,916 \\
\hline
\end{tabular}

According to the official statistics, the proportion of the industrial sector of the capital city and its suburban region as well as of other largest regional cities makes about $56 \%$ of the total industry turnover of Latvia. The Czech market is characterized by low supply level (compared to the market demand), but large turnover in the sector, while in Latvia there are too large volumes of premise space and high level of vacancy rate, that is why supply exceeds the market demand and corresponds to low production capacities. However, there are important differences to be considered - industrial real estate market of Latvia is underdeveloped, the potential of favorable geopolitical situation is not commonly used as significant factor as well as there are significant barriers for the entry of new production plants due to inadequate tax policy, lack of infrastructure development and other reasons.

Growth dynamics of the industrial and agricultural branches in the compared territories is analyzed by making economically justified proportions for development of each mentioned economy branch ("Step 2", "Step 3" in the algorithm model of forecasting supply of spatial economic objects). According to the preliminary research, Swedish stock abroad in manufacturing is approximately at the same level with the FDI inflow assets to this industry in 2009, but it increased significantly after the East-European countries, including the Czech Republic, regained their independence. In comparative analysis, the manufacturing branch value in the national economics increased 1.4 times in the Czech Republic since 1995 and is higher than in Sweden, where the share of manufacturing value added is $15 \%$ from GDP in prices of 2005 . 
Table 3. Coefficient summary of the Latvian forecasted research data comparison to 2009 official data [calculations and presentation made by authors]

\begin{tabular}{|l|c|c|c|}
\hline \multicolumn{1}{|c|}{ Ratio $\backslash$ Country's scenario } & Czech scenario & Swedish scenario & Weighted average \\
\hline $\begin{array}{l}\text { Scenario in a context of } \\
\text { manufacturing branch capacity }\end{array}$ & $\begin{array}{c}\text { Fast growth } \\
\text { (impetuous } \\
\text { development) }\end{array}$ & $\begin{array}{c}\text { Conservative } \\
\text { (2) }\end{array}$ & $\begin{array}{c}\text { Mean } \\
\mathbf{( 3 )}\end{array}$ \\
\hline Manufacturing gross value added & 1.30 & 0.86 & 1.09 \\
\hline Agriculture gross value added & 0.43 & 0.78 & 0.60 \\
\hline $\begin{array}{l}\text { Manufacturing Gross value added } \\
\text { percent from GDP in 2020 }\end{array}$ & 0.73 & 0.70 & 0.71 \\
\hline Productivity per 1 inhabitant & 1.64 & 1.07 & 1.36 \\
\hline $\begin{array}{l}\text { Productivity per 1 sq.m of high- } \\
\text { class industrial property }\end{array}$ & 2.50 & $0.33^{*}$ & 1.33 \\
\hline High-class industrial property stock & 0.53 & 2.91 & 1.72 \\
\hline
\end{tabular}

Note: * B6 (only capital city calculation)

Considering the resulting data of the presented algorithm model of forecasting supply of spatial economic objects ("Step 4"), the authors have come to three scenarios: fast growth, conservative and mean scenario.

In accordance with the obtained results, if the first scenario is implemented, then almost 2 times higher manufacturing productivity can be reached having modern industrial property market, which is by half smaller than the existing one. At the same time, the Swedish scenario reflects the situation when Swedish industry productivity is quite low in comparable prices. This is explained by the lowest inflation rate in Sweden (average annual change in the price index recorded in six leading sectors of the economy in 2000 constant prices from 1998 till 2009 year in the Czech Republic was $0.8 \%$ and in Sweden - 1\%). If the real estate market statistics of Sweden was more widely available, probably, it might have a positive impact on the outcome by increasing the added value of the industrial sector per 1 sq.m. of stock of high-class industrial premises. Forecasts of 2020 for Latvia provide that on average the share of agriculture will fall by slightly more than 2 percentage points compared to the indicators of 2009, in absolute terms, if the added value decreases by $40 \%$. In actual prices, this trend was reversed - increase of 2.6 from the current level, which actually means a significant increase in the consumer price index. According to the information obtained during the study, evaluating in accordance with the industry development scenarios, the forecast according to the Czech scenario with higher industry development rates and lower growth rate of agricultural sector is referred to as "impetuous development" scenario (see Table 3).

Thus, the projected added value of the manufacturing industry from the total economy in calculations of the Latvian National Development Plan is $167 \%$ higher or in other words - too ambitious from the projected Latvian result in comparison with the Czech scenario in the current Research. According to the calculation results, Czech scenario is acceptable for Latvia only if the current market situation considerably changes, that is, the Czech example implies remarkable capital inflows and efficient production. The numbers tell that the projected manufacturing 
capacity of 1.03 compound average annual growth rate would require $53 \%$ less of the current high-class industrial property stock in Latvia.

The Swedish practice is called conservative as it does not suggest fast economy growth, but high-class industrial property stock would need almost 3 times larger space, and, evidently, manufacturing would not be concentrated in the capital city (see the productivity per 1 sq.m of high-class industrial property ratio in Table 3).

According to scenario information, the following development perspective is suggested as a mean scenario: 1) the stock of modern industrial properties could grow up to 772,300 sq.m until 2020; 2) the manufacturing value added of 2020 would increase by 1.09 times from the level of 2009 in comparative prices of 2005, reaching about 2.4 billion Euro turnover at the compound average annual growth rate of 1.01. Here, Latvia would continue regional development, maintain division of industrial capacities and decrease of Riga's industrial agglomeration. In that perspective, the authors suppose that agricultural activities would develop intensively instead of extensively at the lower pace. Increase in high-class industrial property stock is partly founded by the high-quality manufacturing needs and another important factor is the growing needs of the logistics and services.

\section{SCIENTIFIC ASPECTS OF ASSESSMENT OF REGIONAL CONCENTRATION AND SPECIALIZATION OF ENTREPRENEURIAL ACTIVITIES}

To evaluate and measure relative specialization and concentration of entrepreneurial activities, the authors applied the method of the Gini coefficient of Regional Specialization and the Gini coefficient of Geographical Concentration (Falcioğlu and Akgüngör, 2008; Traistaru et al., 2002) from the following mathematical expressions (1) and (3) below:

- Gini coefficient of regional specialization (Damgaard and Weiner, 2000; Falcioğlu and Akgüngör, 2008; Traistaru et al.,2002):

$$
\operatorname{Gini}_{j}^{s}=\left(\frac{2}{n^{2} \bar{R}_{j}}\right)\left[\sum_{i=1}^{n} \lambda_{i}\left|R_{i}-\bar{R}_{j}\right|\right],
$$

where value $\lambda_{i}$ denotes the position of industry $i$ in the ranking of $R_{i}$ ratio (calculated from the share of employment in the industry in a specific region comparing it with the scale of a country's employment in the industry and with a total employment of the chosen region) in descending order, $n$ indicates the number of regions, $m-$ the number of industries. The authors have worked on the modification of formulae (2) for $\bar{R}_{j}$ and (4) for $\bar{C}_{i}$ (Staube, 2013; Staube \& Geipele, 2013b).

$$
\bar{R}_{j}=\frac{1}{m} \sum_{i} R_{i j}
$$


- Gini coefficient of geographical concentration (Falcioğlu and Akgüngör, 2008; Traistaru et al.,2002):

$$
\operatorname{Gini}_{i}^{c}=\left(\frac{2}{m^{2} \bar{C}}\right)\left[\sum_{j=1}^{m} \lambda_{j}\left|C_{j}-\bar{C}_{i}\right|\right],
$$

where value $\lambda_{i}$ denotes the position of industry $i$ in the ranking of $C_{j}$ in descending order, and

$$
\bar{C}_{i}=\frac{1}{n} \sum_{i} C_{i j}
$$

Both Gini coefficients are indices ranging from 0 to 1 . In case of regional specialization, the higher the index, the more specialized the region is. In case of geographical concentration, the higher the index, the greater geographical concentration of the industry is (Paluzie et al., 2001).

In the scientific publication in the proceedings of the International Scientific Conference "Economic Science for Rural Development (Staube \& Geipele, 2013b), the results of the analysis on the foreign control enterprises performed considering the official statistics are presented (European Commission, 2013). As a result, the Gini coefficients given in Table 4 demonstrated a big difference in regional specialization rates of the commercial sectors among three Baltic countries.

Table 4. Gini index calculation results: regional specialization of the analyzed commercial economy sectors in the Baltic States according to NACE rev. 2 coding in 2000, 2007 and 2011, points [calculation and development made by authors]

\begin{tabular}{|l|c|c|c|c|c|c|c|c|}
\hline NACE coding & A-N & A-N & A-N & A-N & A01, C & A01, C & A01, C & A01, C \\
\hline Year $\backslash$ Region & Estonia & Latvia & Lithuania & $\begin{array}{c}\text { Baltic } \\
\text { States }\end{array}$ & Estonia & Latvia & Lithuania & $\begin{array}{c}\text { Baltic } \\
\text { States }\end{array}$ \\
\hline 2000 & 1.00 & 0.73 & 0.48 & 0.73 & 0.35 & 0.04 & 0.11 & 0.17 \\
\hline 2007 & 1.20 & 0.70 & 0.57 & 0.82 & 0.40 & 0.06 & 0.14 & 0.20 \\
\hline 2011 & 1.26 & 0.55 & 0.49 & 0.77 & 0.41 & 0.01 & 0.14 & 0.19 \\
\hline $\begin{array}{l}\text { dynamics, in \% } \\
2000-2011\end{array}$ & 25.31 & -25.04 & 5.50 & 5.27 & 17.04 & -31.50 & 24.79 & 12.83 \\
\hline
\end{tabular}

In the complex calculations on the leading entrepreneurial activities (A-N categories) given in Table 4 and Table 5, the authors resumed that the dominant position was demonstrated by Estonia with Gini index reaching 1.20 points. 
Table 5. Gini index calculation results: geographical concentration of the analyzed commercial economy sectors in the Baltic States according to NACE rev.2 coding from 2000 to 2011, points [calculation and development made by authors]

\begin{tabular}{|l|c|c|c|c|c|c|c|}
\hline $\begin{array}{c}\text { Year/ } \\
\text { NACE coding }\end{array}$ & A & B-E & F & G, I & H, J-N & A01 & C \\
\hline 2000 & 0.45 & 0.13 & 0.11 & 0.29 & 0.52 & 0.51 & 0.12 \\
\hline 2007 & 0.59 & 0.14 & 0.16 & 0.25 & 0.42 & 0.71 & 0.14 \\
\hline 2011 & 0.52 & 0.18 & 0.17 & 0.30 & 0.38 & 0.63 & 0.20 \\
\hline $\begin{array}{l}\text { dynamics, in \% } \\
2000-2011\end{array}$ & 19.63 & 35.95 & 49.73 & 3.47 & -28.90 & 27.73 & 65.02 \\
\hline
\end{tabular}

Of course, high rates may be the results of statistical secrecy and limited number of respondents, but it is rather hard to prove, therefore, the authors may assume the region is highly concentrated in certain sectors (Falcioğlu and Akgüngör, 2008). Latvia was ranked second with regard to the Baltic regional specialization in the period of 2000 to 2011. Economic crisis initiated dramatic changes in this country by 2011 . Latvia demonstrated a remarkable decrease in regional specialization within the Baltics, the most negative Gini index dynamics was observed in agriculture and manufacturing at an average slump of $31 \%$ in the research period, and $88 \%$ during the economic crisis years. From the table above the authors concluded that agriculture and services, including transport, geographically are highly concentrated in the Baltic States. That resulted in 0.52 for A category, 0.63 for A01 category in 2011; 0.52 in 2000 and 0.38 in 2011 for $\mathrm{H}$ and $\mathrm{J}-\mathrm{N}$, respectively. However, manufacturing has shown the lowest rates in the region with very slow dynamics of development: 0.12 in 2000, 0.14 in 2007 and 0.20 in 2011.

- Ricardo model for relative productivity differences TECDIF $_{i}$ (Paluzie et al., 2001; Falcioğlu and Akgüngör, 2008):

$$
\operatorname{TECDIF}_{i}=\sqrt{\frac{1}{m}} \sum_{j}\left[\frac{\frac{V A_{i j}}{E_{i j}}}{\frac{1}{n} \sum_{j} \frac{V A_{i j}}{E_{i j}}}-\frac{\sum_{i} \frac{V A_{i j}}{E_{i j}}}{\frac{1}{n} \sum_{j} \sum_{i} \frac{V A_{i j}}{E_{i j}}}\right]^{2}
$$

Productivity differences are defined as value added per employee (Paluzie et al., 2001) compared by regions and industries. Here, the equation $V A_{i j}$ is a value-added ratio, and $E_{i j}$ - employment (in number of people) of industry $i$ in region $j$. The authors have specified the number of regions using $n$ instead of original $c$ and $n$ for the number of industries from original $m$ to remain the above-mentioned meanings. In result, the calculated amount is the targeted ratio. It does not have unit of measurement due to the fact, it is relative amount.

Performing calculations of the $\mathrm{TECDIF}_{i}$ ratio applying formula (5) the resulting value approximates zero. Therefore, Ricardian theory of the higher the 
degree of regional specialization and the greater the level of geographical concentration of industry and vice versa, is confirmed by the case of Latvia.

\section{CONCLUSION}

1. The authors conducted scientific investigation into the spatial economic allocation that is closely connected with the development of smart cities. Reallocation of resources in the frame of globalization process indicates the content of spatial economics. This concept is not strictly defined in the analytical literature, but quite many scientists have worked to reveal its contents. Therefore, the authors have summarized the factors that make up the essence of the concept of spatial economics, identified its content and have developed the definition of spatial economics.

2. As a result of natural processes as well as human activity, the changes in climatic conditions may have an impact on the country's economic development priorities. Objects of industrial significance are among those commercial real estate market facilities, operation of which even in a short-time may initiate changes in the composition of the air, water and land. Therefore, the average temperature increase has been taken as a determinant in the development of the algorithm model of forecasting supply of spatial economic objects created by the authors.

3. According to the mean scenario of the local industrial real estate property development, the authors concluded: 1) the stock of the modern industrial properties could grow up to 772,300 sq.m until 2020 ; 2) the manufacturing value added of 2020 would increase 1.09 times from the level of 2009 in comparative prices of 2005, reaching about 2.4 billion Euro turnover at the compound average annual growth rate of 1.01. Latvia would continue regional development, maintain division of industrial capacities and decrease of Riga's industrial agglomeration. At that perspective, the authors suggest that agricultural activities would develop intensively instead of extensively at the lower pace. Increase in high-class industrial property stock is conditioned by the high-quality manufacturing needs as well as logistics and service needs.

4. Agriculture and services, including transport, geographically are highly concentrated in the Baltic States. However, Latvia demonstrates low regional specialization rates for agriculture and manufacturing. In the recent years, regional specialization of Latvia significantly decreased as compared to other Baltic States, the most negative Gini index dynamics was recorded in agriculture and manufacturing at a dramatic slump of $88 \%$ during the economic crisis years. The authors stress importance of development of the appropriate infrastructure to create competitive local business environment in the Latvian cities.

\section{REFERENCES}

Āboliņa, K., Andrušaitis, A., Blumberga, D., Briede, A., Bruṇiniece, I., Grišule, G., Kḷaviņš, M. (2008). Klimata main̄̄ba un globālā sasilšana. Riga: LU akadēmiskais apgāds, p. 174. (in Latvian) Alañón-Pardo, Á., Arauzo-Carod, J. M., \& Myro-Sánchez, R. (2007). Accessibility, Agglomeration and Location. In J. M. Arauzo-Carod and M. C. Manjón-Antolín (Eds.), Entrepreneurship, Industrial Location and Economic Growth (pp. 247-267). Chentelham: Edward Elgar. 
Albers, H. J., Ando, A., \& Shogren, J. F. (2010). Introduction to spatial natural resource and environmental economics. Resource and Energy Economics, 32(2), 93-97. https://doi.org/10.1016/j.reseneeco.2009.11.006

Arauzo-Carod, J.-M., \& Viladecans-Marsal, E. (2009). Industrial Location at the Intra-Metropolitan Level: The Role of Agglomeration Economies. Regional Studies, 43(4), 545-558. https://doi.org/10.1080/00343400701874172

Auziņš, A. (2004). Institutional Aspects of Real Estate Property Formation: the Case of Latvia, Proceedings of the International Scientific Conference "Economic Science for Rural Development," Jelgava, Latvia University of Agriculture, (pp. 41-46).

Auziņš, A. (2008). Zemes pārvaldības pamati. Riga: RTU Press, p. 108. (in Latvian)

Barrios, S., Görg, H., \& Strobl, E. (2005). Foreign direct investment, competition and industrial development in the host country. European Economic Review, 49(7), 1761-1784. https://doi.org/10.1016/j.euroecorev.2004.05.005

Brazinskas, S. (2008). The Northern region of the European Union: an economic cooperation outlook for Lithuania. International Journal of Public Administration., 4(20), 19-26.

Brizga, J. (2012). Ilgtspējīga patēriņa pārvaldība Latvijā: pārvaldības instrumenti, sadarbības tīkli un indikatori. Riga: University of Latvia, p. 33. (in Latvian)

Camagni, R. (2005, July). The rationale for territorial cohesion and the place of territorial development policies in the European model of society. Presented at the Vienna Seminar on Territorial cohesion and the European model of society. Retrieved October 12, 2011, from www.intelligentcoast.org/downloads/89_archiv6289_25834.pdf.

CEMAT - Council of Europe Conference of Ministers responsible for Spatial/Regional Planning. (2007). Spatial development glossary. Council of Europe Publishing, Territory and landscape $\begin{array}{lllll}\text { vol. 2. } & \text { Retrieved } & \text { January } & \text { 2013, from }\end{array}$ http://www.coe.int/t/dg4/cultureheritage/heritage/cemat/VersionGlossaire/Bilingue-en-fr.pdf.

Central Statistical Bureau of Czech Republic. (n.d.). Database and site information. Retrieved August 14, 2010, from http://www.czso.cz.

Central Statistical Bureau of Latvia (n.d.). Database and site information. Retrieved January 19, 2011, from http://www.csb.gov.lv/.

Colliers International. (n.d.). Real Estate Market Review. Baltic States and Belarus 2010. Retrieved August 20, 2010, from www.colliers.lv.

Cross-Sectoral Coordination centre. (n.d.). National Development Plan for 2014-2020. Retrieved December 20, 2012 from http://www.nap.lv.

Crozet, M., Mayer, T., \& Mucchielli, J.-L. (2004). How do firms agglomerate? A study of FDI in France. Regional Science and Urban Economics, 34(1), 27-54. https://doi.org/10.1016/s01660462(03)00010-3

Damgaard, C., \& Weiner, J. (2000). Describing Inequality in Plant Size or Fecundity. Ecology, 81(4), 1139-1142. https://doi.org/10.2307/177185

Dühr, S., Colomb, C., \& Nadin, V. (2010). European Spatial Planning and Territorial Cooperation (1st ed.). London: Routledge, p. 488.

Eichengreen, B. (1993). Labour markets and the European Monetary unification. In P. R. Masson and M. P. Taylor (Eds.). Policy issues in the operation of currency unions (pp. 130-162). Cambridge University Press.

European Commission. (2011). Report of the Meeting of Advisory group. ICT Infrastructure for energy-efficient buildings and neighborhoods for carbon-neutral cities. Advisory Group Workshop, 1609/2011. Retrieved July 4, 2014, from http://ec.europa.eu/information_society/activities/sustainable_growth/cities/index_en.htm.

European Commission. (2013). Projects Information and Statistics. Retrieved January 2, 2013, from http://ec.europa.eu/eurostat.

European Commission. (2014). Smart Cities Stakeholder Platform. Retrieved September 4, 2014, from http://eu-smartcities.eu/.

European Environment Agency (EEA). (2010). The European environment. State and outlook 2010. Land use. Retrieved January 14, 2011, from http://www.eea.europa.eu/soer.

Euromonitor International. (2010). World Economic Prospects 2010 (8th ed.). Retrieved August 10, 2010, from http://www.euromonitor.com/World. 
Falcioğlu, P., \& Akgüngör, S. (2008). Regional Specialization and Industrial Concentration Patterns in the Turkish Manufacturing Industry: An Assessment for the 1980-2000 Period1. European Planning Studies, 16(2), 303-323. https://doi.org/10.1080/09654310701814678

Fujita, M., Krugman, P., \& Venables, A. J. (2001). The spatial economy: cities, regions, and international trade. Massachusets: MIT press, p. 359.

Geipele, I. (2007). Tirgvedības stratēgiskā vadīšana būvniecībāa. Riga: RTU Press, p. 318. (in Latvian)

Grizāns, J., \& Vanags, J. (2010). Perspectives of the Modeling of the Latvian Rural - Urban Partnership at the Context of Sustainable Development, Proceedings of the 23rd International Scientific Conference "Economic Science for Rural Development", Jelgava, Latvia University of Agriculture, (pp. 63-69).

Hanink, D. M., \& Cromley, R. G. (1987). Minimizing the geographical risk of foreign direct investment. Geoforum, 18(3), 247-256. https://doi.org/10.1016/0016-7185(87)90010-8

Healey, P. (2005). Aspects of stakeholder engagement in the property development process. Journal of Planning Education and Research, 25, 121-130.

Bas, C. L., \& Sierra, C. (2002). "Location versus home country advantages" in R\&D activities: some further results on multinationals' locational strategies. Research Policy, 31(4), 589-609. https://doi.org/10.1016/s0048-7333(01)00128-7

International Monetary Fund. (2010). Statistics on Macroeconomy. Retrieved August 20, 2010, from http://www.imf.org/external/pubs/ft/weo/2010/01/weodata/.

Kaklauskas, A., Kelpsiene, L., Zavadskas, E. K., Bardauskiene, D., Kaklauskas, G., Urbonas, M., \& Sorakas, V. (2011). Crisis management in construction and real estate: Conceptual modeling at the micro-, meso- and macro-levels. Land Use Policy, 28(1), 280-293. https://doi.org/10.1016/j.landusepol.2010.06.008

King Sturge. (2010). European Industrial Real Estate Market 2010. Retrieved August 20, 2010, from http://www.kingsturge.com/.

Kḷaviņš, M., \& Āboliṇa, K. (2008). Globālā sasilšana un Latvija. In G. Reires (Ed.). Klimata pārmaiņas: izaicinājumi Latvijai starptautiskajā vide (pp. 22-43). Riga: Zinātne Publishing House. (in Latvian)

Krugman, P. (1991). Geography and Trade. Cambridge: MIT Press, p. 156.

Krugman P., \& Venables, A. J. (1990). Integration and the competitiveness of peripheral industry. In Ch. Bliss and J. B. De Macedo (Eds.) Unity with diversity in the European economy: the Community's southern frontier. Cambridge: Cambridge University Press, p. 368.

Latvian Tourism Development Agency. (2010). The climate and weather characteristics in Latvia. Retrieved August 2, 2010, from http://www.latvia.travel/lv/klimats-un-laika-apstakli.

Ministry of Agriculture of Latvia. (2010). Statistical and analytical data of rural development. Retrieved June 26, 2010 from http://www.zm.gov.lv/index.php?sadala=34.

Ministry of Economics of the Republic of Latvia. (2013). Report on the Economic Development of Latvia, June 2001. Retrieved January 3, 2013, from http://www.em.gov.lv.

National Central Statistical Bureau of Sweden. (2013). Retrieved January 2, 2013, from http://www.scb.se.

Obstfeld, M., \& Peri, G. (1998). Regional non-adjustment and fiscal policy. Economic Policy, 13(26), 206-259. https://doi.org/10.1111/1468-0327.00032

Ohlin, B. (1933). Interregional and international trade, Cambridge, MA: Harvard University Press.

Orlovska, A. (2007). Statistika. Riga: RTU Press, p. 111.

Paluzie, E., Pons, J., \& Tirado, D. A. (2001). Regional Integration and Specialization Patterns in Spain. Regional Studies: The Journal of the Regional Studies Association, 35(4), 285-296. https://doi.org/10.1080/00343400120046986

Piccin, J. (2012). Sustainable Development Programs in Rio de Janeiro: Assessing Conflicts between the Environment, Society, and Industry, Proceedings of the 2nd World Sustain. Forum, 1-30 November 2012; Sciforum Electronic Conferences Series.

Pope, V. (2007). Models "key to climate forecasts". BBC News. Retrieved June 26, 2010, from http://news.bbc.co.uk/2/hi/science/nature/6320515.stm.

Ricardo, D. (2004). On the Principles of Political Economy and Taxation. New York: Courier Dover Publications, p. 300. 
Scherbov, S., Mamolo M., \& Lutz W. (2008). Probabilistic Population Projections for the 27 EU Member States Based on Eurostat Assumptions, Working paper, Vienna Institute of Demography, the Austrian Academy of Sciences. p. 75.

Shcherbina, O., Shembelyeva, E., \& Trusins, J. (2010). Spatial Development Decision Making and Modeling. Sustainable Spatial Development, 1, 25-31.

Shepherd, D., \& Bouckova, I. (2004). Czech Agriculture in the Post Communist Period: the story so far. Journal of the Royal Agricultural Society of England, 165, 23-32.

Staniškis, J. (2012). Sustainable consumption and production. Clean Technologies and Environmental Policy, 14(6), 1013-1014.

Staube, T., \& Geipele, I. (2010). Latvijas moderno industriālo telpu ilgtspējīgas attīstības modelis. [Sustainable development model for the modern industrial properties in Latvia]. Economics \& Business, 20, 124-132. (in Latvian)

Staube, T., \& Geipele, I. (2011a). Scientific investigation in spatial planning of the Baltic region, Proceedings of Recent Researches in Urban Sustainability and Green Development (USCUDAR 2011) in Prague, Czech Republic, (pp. 136-141).

Staube, T., \& Geipele, I. (2011b). The latest trends in the spatial planning modelling of the Baltic Sea Region determine a territory's potential, Scientific proceedings of International Conference on Social Sciences and Society (ICSS 2011). USA, Newark: Information Engineering Research Institute, 2, (pp. 403-409).

Staube, T., \& Geipele, I. (2012a) Latvijas industriālo telpu ilgtspējīgā piedāvājuma scenāriju analīze klimata pārmainu ietekmē [Analysis of scenarios on the industrial premises' sustainable supply in Latvia under the influence of the climate change]. In M. Klavins and A. Briede (Eds.), Climate change and adoption to it: Latvia (pp. 170-186). Riga: University of Latvia Press. (in Latvian)

Staube, T., Geipele, I. (2012b). Does Latvia use its advantageous location? in 25th European Conference on Operational Research, Vilnius, Lithuania, July 8-11, 2012, 17-17.

Staube, T. (2013). Issues of spatial economic allocation of the entrepreneurial activities in Latvia (Summary of PhD Thesis). Riga: RTU Press, p. 63.

Staube, T., \& Geipele, I. (2013a). Decisions on Industry Location and Market Capacities in Latvia. Advanced Materials Research, 664, 1141-1145. https://doi.org/10.4028/www.scientific.net/amr.664.1141

Staube, T., \& Geipele, I. (2013b, March). Regional specialization performance to be improved in Latvia for the multinational industrial companies, In Economic Science for Rural Development Conference Proceedings No. 31, (pp. 92-97). ISBN 9789934830471

Staube, T. (2014, January). Feasible industrial location in Latvia: empirical analysis performance for the multinational enterprises. In Environmental Engineering. Proceedings of the International Conference on Environmental Engineering. ICEE (Vol. 9, p. 1). Vilnius Gediminas Technical University, Department of Construction Economics \& Property. https://doi.org/10.3846/enviro.2014.133

Teirumnieks, E. (2010). Ievads un analīze par degradēto teritoriju situāciju Latvijā. Retrieved March 7, 2013, from http://fast10.vsb.cz/bribast/document/MODULE1b_ievads_Latvija.ppt. (in Latvian)

The Met Office. (2010a). The climate change projections map. Retrieved June 26, 2010, from http://www.metoffice.gov.uk/climatechange/science/projections/ensembles_map.html.

The Met Office. (2010b). The ENSEMBLES project information and Final Report. Retrieved July 10, 2010, from http://ensembles-eu.metoffice.com/misc_docs.html.

The New Economy. (2014). The rise of the smart city. Retrieved September 10, 2014, from http://www.theneweconomy.com/technology/the-rise-of-the-smart-city.

The State Forest Service. (2010). Forest research station data. Retrieved July 5, 2010, from http://www.mps.gov.lv/Ecology.html.

The Times. (2013). Business City Guide, Retrieved January 12, 2013, from http://bcg.thetimes.co.uk.

Tourism and information portal Worldtravels. (2010). Retrieved August 2, 2010, from http://www.wordtravels.com.

Traistaru, I., Nijkamp, P., \& Longhi, S. (2002). Regional specialization and concentration of industrial activity in accession countries. Working paper, ZEI, Center for European Integration Studies, Rheinische Friedrich-Wilhelms-Universität, Bonn, B16. 
Tvaronavičius, V., \& Tvaronavičiene, M. (2008). Role of fixed investments in economic growth of country: Lithuania in European context. Journal of Business Economics and Management, 9(1), 57-64. https://doi.org/10.3846/1611-1699.2008.9.57-64

Unpublished material. (2013). E-interview with Paul van der Linden, the Met Office Science Manager on 16 January 2013.

Vanags, J., \& Geipele, I. (2008). Latvijas tautsaimniecība un būvniecības nozares attīstības ietekme uz nekustamā īpašuma tirgu. Riga: RTU Press, p. 196. (in Latvian)

Elabras Veiga, L. B., \& Magrini, A. (2009). Eco-industrial park development in Rio de Janeiro, Brazil: a tool for sustainable development. Journal of Cleaner Production, 17(7), 653-661. https://doi.org/10.1016/j.jclepro.2008.11.009

Vienna UT. Centre of Regional Science Smart cities - Ranking of European medium-sized cities, October 2007. Retrieved August 28, 2014, from http://www.smartcities.eu/download/smart_cities_final_report.pdf.

Waterhout, B. (2011). Dühr S., Colomb C., Nadin V. (2010): European Spatial Planning and Territorial Cooperation. Raumforschung und Raumordnung, 69(1), 63-64. https://doi.org/10.1007/s13147010-0069-8

Yeaple, S. R. (2003). The complex integration strategies of multinationals and cross country dependencies in the structure of foreign direct investment. Journal of International Economics, 60(2), 293-314. https://doi.org/10.1016/s0022-1996(02)00051-x

Zajacs, A., Zemītis, J., Tihomirova, K., \& Borodinecs, A. (2014). Concept of Smart City: First Experience from City of Riga. Journal of Sustainable Architecture and Civil Engineering, 7(2), 54-59. https://doi.org/10.5755/j01.sace.7.2.6932

\section{AUTHORS' SHORT BIOGRAPHIES}

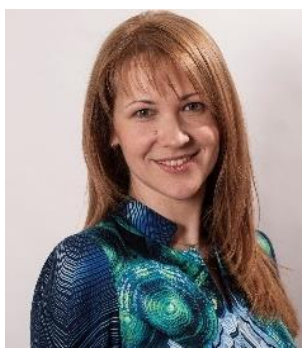

Tatjana Štaube, Dr.oec., Researcher and Assistant Professor at Riga Technical University. Research interests: commercial real estate, feasibility studies, financial analysis, market research, spatial economic allocation, strategic business development planning, sustainable development. Within over 15 years of professional experience she worked with Colliers International, Rimi Latvia, and the Ministry of Environmental Protection and Regional Development of Latvia, participated in 5 international scientific and practical projects. Tatjana Štaube is an author and co-author of over 30 scientific publications. She is an active participant in scientific conferences, congresses and workshops. Dr. Štaube is an awardee of the RTU Senate's scholarship, Student Exchange Programmes in Norway and Finland and FIABCI Scholarship. Mrs. Štaube is an expert in Management and Economic Sciences at the Latvian Council of Science.

ORCID iD: http://orcid.org/0000-0002-7874-0872

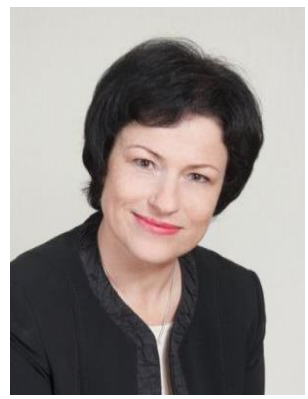

Ineta Geipele is a Professor of the Faculty of Engineering Economics and Management, Director of the Institute of Civil Engineering and Real Estate Economics, the Head of the Department of the Civil Construction and Real Estate Economics and Management at Riga Technical University, Latvia. She improved her professional skills in Austria, Germany, Denmark and the UK. Ineta Geipele is the author and co-author of more than 300 scientific publications. Her current research areas are sustainability development problems of real estate market, construction industry, land use management and institutional economics. Professor Ineta Geipele is an expert of the Latvian Academy of Sciences in Management and Economics Sciences at the Latvian Council of Science, a board member of the FIABCI-Baltic Multinational Chapter and of the Cunfte of the Facility Management of Latvian Housing, and a member of the Latvian Union of Civil Engineers.

ORCID iD: http://orcid.org/0000-0002-2963-087X 


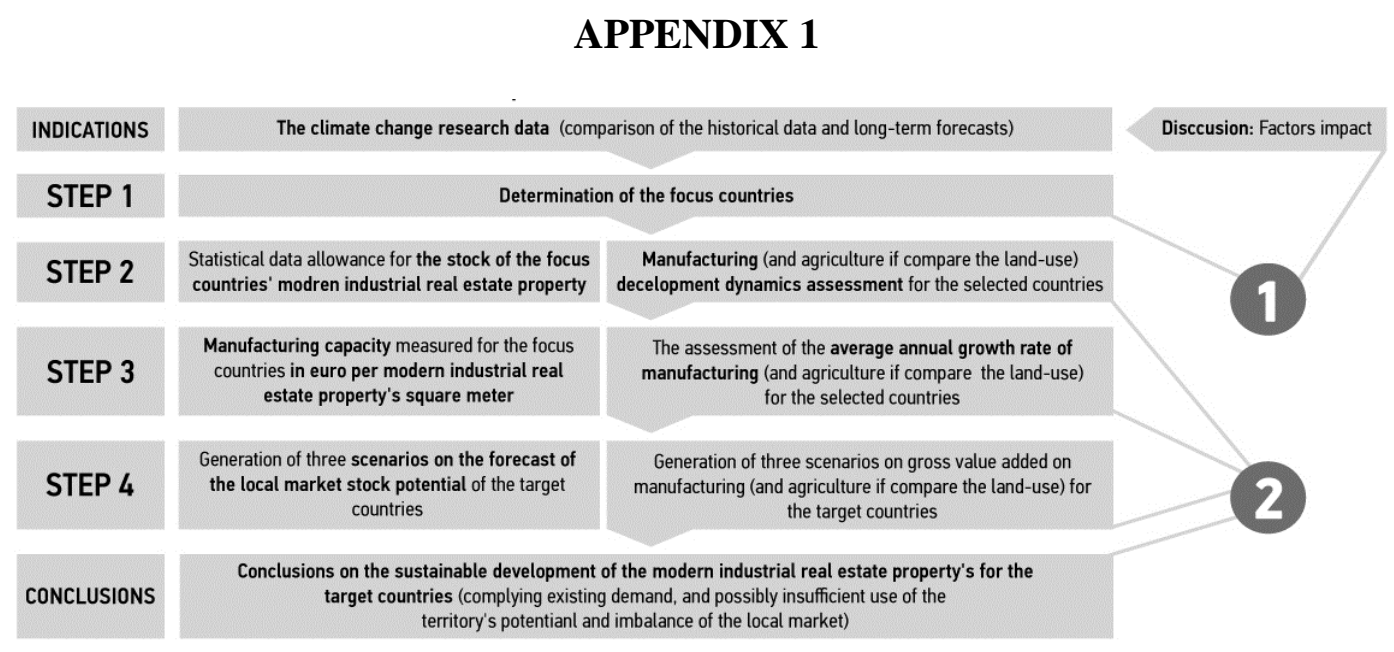

Fig. A1. The algorithm model of forecasting supply of spatial economic objects [developed by authors].

Note: 1 - Modeling of the climate change projections, 2 - Making a forecast on the high-class (modern) industrial property stock and manufacturing capacity. 